\title{
PENGARUH DOSIS PUPUK ORGANIK CAIR TERHADAP PERTUMBUHAN DAN HASIL TANAMAN TERUNG (Solanum melongena L.)
}

\author{
Yustina M.S.W. Pu'u' ${ }^{1}$, Elias Nong Sina ${ }^{2}$ \\ Yus_puu@yahoo.com
}

\section{Program Studi Agroteknologi, Fakultas Pertanian-Universitas Flores}

\begin{abstract}
This research aimed to know the effect and optimum rates of liquid organic fertilizer on the growth and yield of Eggplant.

The research used Randomized Block Designconsisted of 5 rates of liquid organic fertilizer; $(\mathrm{M} 0=\mathrm{control} /$ without fertilizers, $\mathrm{M} 1=1$ liters ha-1, M2 = 1 ha-2 litres, M3 = 3 liters ha-1, M4 = 4 liters ha-1). The observed variable is the height of plants, number and leaf area, length of fruit, fruit diameter, number of fruit, weight of fruit per plant,weight of fruit per hectar,fresh residues per plant, and fresh residues per hectarand harvest index.

The result of experiment showed the rates of liquid organic fertilizereffect on percentage of the growth and yield of eggplant; they are; height of plants $(6,22 \%)$, leaf number $(28,20 \%)$, leaf area $(29,58 \%)$, length of eggplant $(43,11 \%)$, eggplant diameter $(9,00 \%)$, number of eggplant $(22,03 \%)$, weight of eggplant per plant $(25,62 \%)$, weight of eggplant per hectar $(16,70 \%)$, fress residues per plant $(28,58 \%)$, residues per hectar $(34,93 \%)$, and harvest index $(53,91 \%)$. Optimum rates of liquid organic fertilizer which effect on the growth and yield of eggplant are about 4 liter ha ${ }^{-1}$.
\end{abstract}

Keywords: rates, Liquid Organic, Eggplant.

\section{Pendahuluan}

Tanaman terung (Solanum

melongena L.) merupakan tanaman sayuran yang mampu tumbuh pada lingkungan dan jenis tanah yang berbeda. Tanah yang cocok untuk ditanami tanaman terung adalah tanah pada daerah yang beriklim sedang dengan ketinggian tempat yang bervariasi antara 700 sampai $1500 \mathrm{~m}$ dari permukaan laut (Susila, 2006). Pada umumnya tanaman terung tidak membutuhkan hujan sehingga dapat dikatakan bahwa tanaman terung sangat membutuhkan sinar matahari yang relatif cukup untuk pertumbuhan dan perkembangannya.

Produksi tanaman terung di tingkat Nasional pada tahun 2009 dan 2010 dengan luas tanam 12.307 ha sebesar 451.564 ton dan 482.305 ton sehingga produktivitasnya sebesar 36,69 ton ha ${ }^{-1}$ dan 39,19 ton ha-1 (Badan Penelitian dan 
Yustina: Pengaruh dosis pupuk organik cair terhadap pertumbuhan dan hasil tanaman terung (Solanum melongena L.)

Pengembangan Pertanian, 2011).

pertumbuhan dan hasil tanaman terung

Produksi tanaman terung di Nusa dengan melakukan pemupukan yang Tenggara Timur (NTT) pada tahun 2009 dan 2010 dengan luas tanam sebesar 206,3 ha sebesar 5.851 ton dan 4.943 ton sehingga produktivitasnya sebesar 28,4 ton ha ${ }^{-1}$ dan 23,96 ton ha ${ }^{-1}$ (Badan Pusat Statistik Provinsi NTT, 2011). Kabupaten Ende yang juga sebagian petani menanam tanaman terung walaupun dalam luasan yang kecil, pada tahun 2009 dan 2010 dengan luas tanam 9,2 ha mencapai produksi sebesar 5,05 ton dan 4,55 ton sehingga produktivitasnya mencapai 0,55 ton $\mathrm{ha}^{-1}$ dan 0,49 ton $\mathrm{ha}^{-1}$ (Dinas Pertanian Kabupaten Ende. ,2011). Data tersebut menunjukkan bahwa produksi dan produktivitas terung di Kabupaten Ende masih Rendahnya produksi dan produktivitas terung di kabupaten Ende dibandingkan Propinsi dan Nasional. Salah satu penyebab permasalahan tersebut dari faktor budidaya yaitu kegiatan pemupukan yang tidak dilakukan secara optimal dan kondisi nyata yang ada di masyarakat biasanya tidak pernah memberikan pupuk pada tanaman terung. Untuk mengatasi permasalahan pemupukan maka upaya yang dapat dilakukan dalam peningkatan

optimal serta tidak merusak lingkungan tumbuh dan sekitar masyarakat yaitu dengan pemanfaatan pupuk organik cair.

Pupuk organik cair memiliki manfaat yang sangat penting bagi tanaman karena mengadung unsur hara mikro dan makro $\mathrm{N}, \mathrm{P}, \mathrm{K}, \mathrm{Ca}, \mathrm{Mg}, \mathrm{Al}$, $\mathrm{Fe}, \mathrm{Mn}, \mathrm{Cu}, \mathrm{Zn}$, dan $\mathrm{C}$ organik, pupuk organik cair mempunyai beberapa fungsi yaitu dapat memperbaiki sifat fisik, kimia, dan biologi tanah, dan membantu meningkatkan produksi tanaman. Pupuk organik cair juga dapat meningkatkan daya tahan tanaman terhadap kekeringan, pembentukkan bunga dan buah, serta mengurangi penggunaan pupuk anorganik sebagai pengganti pupuk kandang (Parman, 2007). Pupuk organik cair mempunyai peranan merangsang pertumbuhan tanaman secara keseluruhan, khususnya batang, cabang dan daun, serta penting dalam pembentukan hijau daun yang berguna dalam pembentukan fotosintesis. Pengunaan pupuk majemuk untuk tanaman sayuran yang sangat baik dan lebih efisien dibandingkan dengan penggunaan pupuk tunggal. Unsur hara 
Yustina: Pengaruh dosis pupuk organik cair terhadap pertumbuhan dan hasil tanaman terung (Solanum melongena L.)

pupuk yang diberikan lebih lengkap dan tidak ada persoalan pencampuran pupuk. Ignasius dkk (2014) mengemukakan bahwa tanaman terung membutuhkan unsur hara makro serta unsur hara mikro yang cukup untuk pertumbuhan, apabila unsur hara yang diperlukan tidak cukup tersedia diantaranya unsur hara $\mathrm{N}, \mathrm{P}, \mathrm{K}$. Nitrogen diperlukan tanaman terung selama masa pertumbuhan sampai pemasakan buah, tanaman terung menghendaki tersedianya $\mathrm{N}$ secara terus menerus pada semua stadia pertumbuhan. Kekurangan unsur hara $\mathrm{N}$ tanaman menjadi kerdil dan daun terung menjadi keriput.

Berdasarkan keterangan pada label pupuk organik cair adalah pupuk organik yang berbentuk cair dan penggunaanya dapat dicampur dengan air dan disemprotkan lewat daun dengan dosis penggunaanya; 2-3 liter ha ${ }^{-1}$ (10cc dalam 10 liter air) untuk tanman sayuran. Unsurunsur yang terkandung di dalamnya adalah Nitrogen (Total-N), Fospor (P2O5), dan Kalium (K2O), Sulfur (S unsur), Magnesium (Mg0), Kalsium (Ca0), Tembaga ( $\mathrm{Cu}$ unsur), Seng ( $\mathrm{Zn}$ unsur),Total Mn, Fe, Mo, dan E, Bahan organik, dan $\mathrm{pH}$ untuk pertumbuhan dan perkembangan. Penelitian ini bertujuan untuk mengetahui pengaruh dosis pupuk organik cair serta dosis optimumnya terhadap pertumbuhan dan hasil tanaman terung.

\section{METODE PENELITIAN}

\section{Tempat dan Waktu}

Percobaan ini dilakukan di kebun percobaan Badan Penyuluhan Pertanian (BPP) di Desa Riaraja Kecamatan Ende Kabupaten Ende. Percobaan ini dilakukan selama 5 bulan yakni dari bulan Desember 2012 sampai dengan bulan April tahun 2013.

\section{Bahan dan Alat}

Adapun bahan yang digunakan dalam penelitian ini adalah benih terung, pupuk organik cair Mitra Flora dan pupuk kandang (kotoran ayam). Alat yang digunakan dalam penelitian ini adalah, ember, kantong plastik, timbangan, handsprayer, kalkulator, meteran, pacul, sabit, parang, skop, dan alat tulis lainya.

\section{Rancangan Percobaan}

Penelitian ini dirancang dengan menggunakan Rancangan Acak Kelompok (RAK) dengan 5 perlakuan yaitu:

$$
\begin{aligned}
& \text { M0 : } 0 \text { Liter ha }{ }^{-1} \text { atau tanpa pupuk } \\
& \text { organik cair }
\end{aligned}
$$


Yustina: Pengaruh dosis pupuk organik cair terhadap pertumbuhan dan hasil tanaman terung (Solanum melongena L.)

M1 : 1 Liter ha ${ }^{-1}$ pupuk organik cair M2 : 2 Liter ha $^{-1}$ pupuk organik cair M3 : 3 Liter ha ${ }^{-1}$ pupuk organik cair M4 : 4 Liter ha ${ }^{-1}$ pupuk organik cair

Perlakuan diulang sebanyak 4 kali sehingga terdapat 20 satuan percobaan.

\section{Pelaksanaan Penelitian}

\section{Persiapan Lahan}

Lahan percobaan dibersihkan dari gulma sisa tanaman sebelumnya. Lahan yang sudah dibersihkan langsung dibajak dengan kedalaman 15 sampai $20 \mathrm{~cm}$. Tujuan pengolahan tanah agar menjadi tanah gembur sehingga akar tanaman dapat mudah menembus tanah. Selanjutnya dibuat bedengan dengan ukuran 2,8 x 3,6 meter. Tinggi bedengan $30 \mathrm{~cm}$, dengan jarak antara bedengan 40 $\mathrm{cm}$ dan jarak antara ulangan $40 \mathrm{~cm}$.

\section{Pembibitan}

Tahapan-tahapan yang dilakukan dalam proses pembibitan, yakni:

1. Benih direndam dengan air hangat selama 10-15 menit sebelum disemaikan.

2. Benih dibungkus dengan kain basah dan diperam selama \pm 24 jam hingga nampak mulai berkecambah.

3. Benih ditebarkan di atas bedengan persemaian dengan jarak antar baris
10-15 $\mathrm{cm}$ dan ditutup dengan tanah tipis-tipis, diikuti dengan penutupan bedengan persemaian dengan menggunakan daun pisang.

4. Benih siap dipindah-tanamkan setelah mulai berkecambah pada umur 1 bulan atau sudah berdaun 4 helai.

\section{Penanaman}

Penanaman terung dilakukan pada pada saat bibit terung berumur 4 minggu. Sebelum ditanam, pilih bibit yang tumbuh subur dan normal, tanam bibit dilubang tanam yang sudah siapkan dengan jarak tanam $60 \times 70 \mathrm{~cm}$. Selanjutnya tanaman di siram dengan air yang cukup.

\section{Pemupukan}

Pemupukan diawali dengan menggunakan pupuk dasar, yaitu pupuk kandang ayam dengan dosis 2 ton/hektar $(2,016 \mathrm{~kg} /$ petak). Sehingga diaplikasikan ke 20 petak percobaan membutuhkan 40,32 $\mathrm{kg}$ yang diberikan 1 minggu sebelum tanam. Kemudian dilanjutkan dengan pupuk susulan, yaitu pupuk organik cair yang diberikan sesuai dosis perlakuan yaitu $\mathrm{M} 0=$ Kontrol; $\mathrm{M} 1=1$ liter ha ${ }^{-1}=10,08 \times 1000: 10.000=1,008$ $\mathrm{ml} \operatorname{petak}^{-1} ; \mathrm{M} 2=2$ liter $\mathrm{ha}^{-1}=10,08 \mathrm{x}$ $2000: 10.000=2,016 \mathrm{ml} \mathrm{petak}^{-1} ; \mathrm{M} 3=3$ liter ha $\mathrm{a}^{-1}=10,08 \times 3000: 10.000=3,024$ 
Yustina: Pengaruh dosis pupuk organik cair terhadap pertumbuhan dan hasil tanaman terung (Solanum melongena L.)

ml petak $^{-1} ; \mathrm{M} 4=4$ liter $\mathrm{ha}^{-1}=10,08 \mathrm{x}$ $4000: 10.000=4,032 \mathrm{ml}$ petak $^{-1}$. Pemberian sebanyak 2 kali pada umur 3 MST dan 5 MST sehingga masingmasing perlakuan diberikan $1 / 2$ dari dosis pupuk yaitu M0= Kontrol; M1=0,504 ml $\operatorname{petak}^{-1} ; \quad \mathrm{M} 2=1,008 \mathrm{ml}$ petak $^{-1} ; \mathrm{M} 3=$ $1,512 \mathrm{ml} \operatorname{petak}^{-1} ; \mathrm{M} 4=2,016 \mathrm{ml} \operatorname{petak}^{-1}$ dan setiap dosis diencerkan dengan air sebanyak 5 liter. Pemberian dengan cara disemprotkan pada tanaman di setiap petak percobaan menggunakan handsprayer.

\section{Pemeliharaan Tanaman}

Penyiraman dilakukan sejak penanaman dengan selalu memperhatikan kondisi tanaman di lapangan dilakukan pada pagi dan sore hari dengan menggunakan gembor.

Penyulaman dilakukan pada saat tanaman berumur 10 hst.

\section{Pemasangan Ajir (turus)}

Dilakukan pada umur tanaman 2 MST (minggu setelah tanam), agar tidak mengganggu (merusak) sistem perakaran,dan turus terbuat dari bilah bambu setinggi $80-100 \mathrm{~cm}$ dan lebar 2-4 $\mathrm{cm}$. Tancapkan secara individu dekat batang, ikat batang atau cabang terung pada turus.

\section{Penyiangan}

Rumput liar atau gulma di sekitar tanaman disiangi atau dicabut,penyiangan dilakukan pada umur 15 hari dan 60-75 hari setelah tanam.

\section{Pemangkasan (Perempelan)}

Pangkas tunas-tunas liar yang tumbuh mulai dari ketiak daun pertama hingga bunga, kegiatan ini dilakukan pada umur tanaman 4 MST.

\section{Pemanenan}

Kegiatan panen direncanakan sebanyak empat kali yaitu pada umur tanam 8 MST, 9 MST, 10 MST, 11 MST. Ciri-ciri buah siap panen adalah ukuranya telah maksimum dan masih muda. Waktu pemanenan yang paling tepat pagi atau sore hari. Cara panen buah dipetik bersama tangkainya dengan alat yang tajam atau gunting pemotong buah.

\section{Variabel Pengamatan}

Pengamatan yang di rencanakan di bagi atas 2 bagian yakni pada fase generatif dan fase vegetatif dimana masing-masing fase 3 kali pengamatan dengan interval waktu 1 minggu sekali. Dengan variabel yang diamati adalah tinggi tanaman, jumlah daun, luas daun, panjang buah, diameter buah, jumlah buah tanaman, berat buah tanaman, berat 
Yustina: Pengaruh dosis pupuk organik cair terhadap pertumbuhan dan hasil tanaman terung (Solanum melongena L.)

buah $\mathrm{ha}^{-1}$, berat brangkasan segar tanaman $^{-1}$, berat brangkasan segar $\mathrm{ha}^{-1}$ dan Indeks panen.

\section{Analisis Data}

Data hasil pengamatan dianalisis dengan sidik ragam sesuai dengan rancangan yang digunakan apabila perlakuan menunjukkan pengaruh nyata terhadap variabel yang diamati, maka dilanjutkan dengan uji BNT taraf $5 \%$

(Gomez dan Gomez, 1995).

\section{HASIL DAN PEMBAHASAN}

Hasil analisis statistik menunjukan bahwa dosis pupuk organik berpengaruh sangat nyata terhadap jumlah daun dan luas daun serta berpengaruh tidak nyata pada tinggi tanaman (Tabel 4.2).

Tabel 4.2. Pengaruh Dosis Pupuk Organik Cair Mitra Flora Terhadap Tinggi tanaman, Jumlah Daun, dan Luas Daun Tanaman Terung pada setiap Umur Pengamatan

\begin{tabular}{|c|c|c|c|c|}
\hline \multirow{2}{*}{ Variabel } & \multirow{2}{*}{ Perlakuan } & \multicolumn{3}{|c|}{ Umur Pengamatan (hst) } \\
\hline & & 14 Hst & 21 Hst & $28 \mathrm{Hst}$ \\
\hline \multirow{5}{*}{$\begin{array}{l}\text { Tinggi } \\
\text { Tanaman } \\
(\mathbf{c m})\end{array}$} & M0 & $22,48 \mathrm{a}$ & $44,08 \mathrm{a}$ & $90,38 \mathrm{a}$ \\
\hline & M1 & $22,98 \mathrm{a}$ & $44,35 \mathrm{a}$ & $92,25 \mathrm{a}$ \\
\hline & M2 & $23,75 \mathrm{a}$ & $45,78 \mathrm{a}$ & $92,25 \mathrm{a}$ \\
\hline & M3 & $24,00 \mathrm{a}$ & $46,40 \mathrm{a}$ & $94,80 \mathrm{a}$ \\
\hline & M4 & $24,28 \mathrm{a}$ & $47,00 \mathrm{a}$ & $95,83 \mathrm{a}$ \\
\hline \multicolumn{2}{|c|}{ BNT 5\% } & - & - & - \\
\hline \multirow{5}{*}{$\begin{array}{c}\text { Jumlah Daun } \\
\text { (helai) }\end{array}$} & M0 & $12,75 \mathrm{~b}$ & $16,00 \mathrm{~b}$ & $17,00 \mathrm{~b}$ \\
\hline & M1 & $13,25 \mathrm{~b}$ & $17,00 \mathrm{~b}$ & $19,00 \mathrm{~b}$ \\
\hline & M2 & $14,50 \mathrm{ab}$ & $18,50 \mathrm{~b}$ & $20,75 \mathrm{~b}$ \\
\hline & M3 & $15,25 \mathrm{a}$ & $18,50 \mathrm{~b}$ & $22,75 \mathrm{~b}$ \\
\hline & M4 & $19,75 \mathrm{a}$ & $22,00 \mathrm{a}$ & $22,75 \mathrm{a}$ \\
\hline \multicolumn{2}{|c|}{ BNT 5\% } & 4,60 & 1,91 & 3,02 \\
\hline \multirow{5}{*}{$\begin{array}{l}\text { Luas Daun } \\
\qquad\left(\mathbf{c m}^{2}\right)\end{array}$} & MO & $40,70 \mathrm{c}$ & $95,17 \quad b$ & $159,26 \mathrm{c}$ \\
\hline & M1 & $44,12 \mathrm{~b}$ & $110,19 a b$ & $217,28 \mathrm{~b}$ \\
\hline & M2 & $45,85 \mathrm{~b}$ & $112,92 \mathrm{ab}$ & $225,47 \mathrm{~b}$ \\
\hline & M3 & $46,07 \mathrm{~b}$ & $115,63 \mathrm{a}$ & $243,58 \mathrm{a}$ \\
\hline & M4 & 53,47 a & $118,36 \mathrm{a}$ & 247,29 a \\
\hline & & 1,48 & 4,63 & 10,12 \\
\hline
\end{tabular}

Keterangan : Angka-angka yang diikuti oleh huruf yang sama pada kolom yang sama menunjukan tidak berbeda nyata pada taraf 5\% uji BNT. 
Yustina: Pengaruh dosis pupuk organik cair terhadap pertumbuhan dan hasil tanaman terung (Solanum melongena L.)

Pemberian pupuk organik cair Mitra Flora memberikan pengaruh terhadap tinggi tanaman, jumlah daun dan luas daun yang mengalami peningkatan pada setiap perlakuan dimana pada perlakuan dosis 0 liter (MO) ke 1 liter ha1 (M1) meningkat rataan total sebesar $(1,65 \%), \quad(5,45 \%)$ dan $(8,39 \%)$, perlakuan 1 1iter ha ${ }^{-1}$ (M1) ke 2 liter ha ${ }^{-1}$ (M2) meningkat rataan total sebesar (1,36 $\%),(5,61 \%)$ dan $(2,22 \%)$, perlakuan 2 liter ha- ${ }^{-1}$ (M2) ke 3 liter ha ${ }^{-1}$ (M3) sebesar $(2,07 \%), \quad(1,38 \%)$ dan $(3,90 \%)$, perlakuan 3 liter ha-1 $($ M3) ke 4 liter ha-1 (M4) meningkat rataan total sebesar $(1,14$ $\%),(18,42 \%)$ dan $(7,85 \%)$.

Perlakuan dosis pupuk organik cair Mitra Flora 3 liter ha ${ }^{-1}$ (M3) memberikan pertumbuhan luas daun tanaman terung paling baik walaupun tidak berbeda nyata dengan dosis 4 liter ha $^{-1}$ (M4) pada perlakuan luas daun umur 21 hst dan umur 28 hst. Sedangkan untuk jumlah daun yang terbaik pada perlakukan M4. Hal ini diduga karena kandungan hara berdasarkan hasil analisis tanah awal yaitu $\mathrm{N}$ : $0.14 \%$ (rendah) $\mathrm{C}$ organik 0,92\% (rendah), DHL 6,4\%, P 20,20\%, K $95,26 \%$, sehingga pertumbuhan tinggi tanaman, jumlah daun dan luas daun tanaman terung dengan dosis yang diberikan belum menunjukan perbedaan yang nyata. Pupuk organik cair memiliki kandungan unsur hara $\mathrm{N} \mathrm{0,32 \% ,} \mathrm{P} \mathrm{0,91}$ $\%$, K 3,22 \%, Ca 18\%, bahan organik $14 \%$, total unsur mikro $\mathrm{Zn}, \mathrm{Cu}, \mathrm{Co}, \mathrm{Mn}$, $\mathrm{Fe}$, Mo, dan B 250 Ppm, vitamin, protein dan enzim.

Hasil analisis sidik ragam menunjukan bahwa dosis pupuk organik cair Mitra Flora memberikan pengaruh sangat nyata terhadap panjang buah, diameter buah, jumlah bauh, berat buah per $\tan ^{-1}$, berat buah per $\mathrm{ha}^{-1}$, berat brangkasan segar $\tan ^{-1}$, berat brangkasan segar ha $^{-1}$ dan indeks panen tanaman terung (Tabel 4.3).

Perlakuan dosis 0 liter ha ${ }^{-1}(\mathrm{MO}) \mathrm{ke}$ 1 liter/Ha (M1) meningkat rataan total sebesar (24,39\%), (6,47\%), (9,35\%), $(19,73 \%),(19,75 \%),(8,81 \%),(8,82$ $\%)$ dan ( $18,93 \%)$, pada perlakuan 1 liter ha $^{-1}$ (M1) ke 2 liter ha ${ }^{-1}$ (M2) meningkat rataan total sebesar $(9,94 \%),(1,45 \%)$, $(1,97 \%),(3,98 \%),(3,99 \%),(11,17$ $\%),(11,17 \%)$ dan( $(2,75 \%)$, perlakuan 2 liter ha $\mathrm{ha}^{-1}$ (M2) ke 3 liter $\mathrm{ha}^{-1}$ (M3) mengalami peningkatan rataan total sebesar $(5,83 \%),(0,76 \%),(5,42 \%)$, $(1,05 \%),(1,03 \%),(5,27 \%),(5,25 \%)$ 
Yustina: Pengaruh dosis pupuk organik cair terhadap pertumbuhan dan hasil tanaman terung (Solanum melongena L.)

dan $(5,25 \%)$, pada perlakuan 3 liter $\mathrm{ha}^{-1}$ (M3) ke 4 liter ha $^{-1}$ (M4) meningkat rataan total sebesar $(11,29 \%),(0,52 \%)$, $(7,32 \%),(2,47 \%),(2,45 \%),(6,92 \%)$,
$(6,95 \%)$ dan(0,22 \%). Unsur hara P dan $\mathrm{K}$ yang dibutuhkan untuk fase generative tersedia cukup dengan peningkatan dosis sehingga hasil meningkat.

Tabel 4.3.Pengaruh Pemberian Dosis Pupuk Organik Cair Terhadap Hasil Tanaman Terung

\begin{tabular}{clccccccc}
\hline Perlakuan & $\begin{array}{c}\text { PB T/Tan } \\
(\mathbf{c m})\end{array}$ & $\begin{array}{c}\text { DB T/Tan } \\
(\mathbf{m m})\end{array}$ & $\begin{array}{c}\text { JB T/Tan } \\
\text { (buah) }\end{array}$ & $\begin{array}{c}\text { BB } \\
\text { T/Tan.(g) }\end{array}$ & $\begin{array}{c}\text { BB } \\
\text { Ha (ton) }\end{array}$ & $\begin{array}{c}\text { BBS } \\
\text { Tan }(\mathbf{g})\end{array}$ & $\begin{array}{c}\text { BBS } \\
\text { Ha }(\mathbf{g})\end{array}$ & $\begin{array}{c}\text { Indeks } \\
\text { Panen }\end{array}$ \\
\cline { 2 - 8 } M0 & $11,44 \mathrm{~b}$ & $47,14 \mathrm{~b}$ & $4,85 \mathrm{e}$ & $312,32 \mathrm{~d}$ & $25,74 \mathrm{~d}$ & $362,50 \mathrm{e}$ & $22,75 \mathrm{~d}$ & $0,53 \mathrm{~b}$ \\
M1 & $15,13 \mathrm{ab}$ & $50,40 \mathrm{a}$ & $5,35 \mathrm{~d}$ & $389,10 \mathrm{c}$ & $27,06 \mathrm{c}$ & $379,50 \mathrm{~d}$ & $26,72 \mathrm{c}$ & $0,54 \mathrm{~b}$ \\
M2 & $16,80 \mathrm{ab}$ & $51,14 \mathrm{a}$ & $5,45 \mathrm{c}$ & $405,22 \mathrm{~b}$ & $28,60 \mathrm{~b}$ & $447,50 \mathrm{c}$ & $30,46 \mathrm{~b}$ & $0,68 \mathrm{~b}$ \\
M3 & $17,84 \mathrm{a}$ & $51,53 \mathrm{a}$ & $5,76 \mathrm{~b}$ & $409,05 \mathrm{a}$ & $29,00 \mathrm{~b}$ & $472,36 \mathrm{~b}$ & $34,72 \mathrm{a}$ & $1,05 \mathrm{a}$ \\
M4 & $20,11 \mathrm{a}$ & $51,80 \mathrm{a}$ & $6,22 \mathrm{a}$ & $419,88 \mathrm{a}$ & $30,90 \mathrm{a}$ & $507,54 \mathrm{a}$ & $34,96 \mathrm{a}$ & $1,15 \mathrm{a}$ \\
\hline BNT 5\% & $\mathbf{7 , 0 0}$ & $\mathbf{2 , 7 8}$ & $\mathbf{0 , 3 2}$ & $\mathbf{1 8 , 6 4}$ & $\mathbf{1 , 4 5}$ & $\mathbf{7 , 7 0}$ & $\mathbf{2 , 4 2}$ & $\mathbf{0 , 2}$ \\
\hline
\end{tabular}

Keterangan :

PB T/Tan : : Panjang Buah Total Pertanaman

DB T/Tan : Diameter Buah Total Pertanaman

JB T/Tan : Jumlah Buah Total Pertanaman

BB : Berat Buah

BBS : Berat Berangkas Segar

Dosis pupuk organik cair 3 liter ha- ${ }^{-1}$

memberikan hasil tanaman terung yang

optimal walaupun tidak berbeda nyata dengan dosis 4 liter ha ${ }^{-1}$. Hal ini didukung dengan kondisi tanah awal di lokasi penelitian memiliki kandungan unsure hara $\mathrm{P} 20,20 \%$ (sedang) dan $\mathrm{K}$ tersedia $95,26 \%$ (rendah) sehingga dengan penambahan pupuk organik cair dapat meningkatkan kandungan unsur hara tersebut sehingga terjadi peningkatan hasil tanaman terung. Hasil ini sesuai dengan pernyataan Ignatius (2014) bahwa tanaman terung membutuhkan unsur hara makro serta unsur hara mikro yang cukup untuk pertumbuhan, apabila unsur hara yang diperlukan tidak cukup tersedia diantaranya unsur hara N, P, K.

Pupuk organik cair mitra flora memiliki kandungan unsur hara $\mathrm{N} 0,32$ $\%$, P 0,91 \%, K 3,22 \%, Ca 18\%, bahan organik 14\%, total unsur mikro $\mathrm{Zn}, \mathrm{Cu}$, Co, Mn, Fe, Mo, dan B 250 Ppm, vitamin, protein dan enzim yang berfungsi untuk berperan dalam proses pemindahan hara tanaman, meningkatkan asmose sel, mencegah kehilangan air yang tidak seimbang.

\section{Kesimpulan}

1. Peningkatan dosis pupuk organik cair berpengaruh terhadap peningkatan pertumbuahan dan hasil tanaman 
Yustina: Pengaruh dosis pupuk organik cair terhadap pertumbuhan dan hasil tanaman terung (Solanum melongena L.)

terung dimana rata-rata pada variabel pertumbuhan tinggi tanaman $(1,14 \%)$, pertumbuahan jumlah daun $(18,42 \%)$ dan luas daun $(7,85 \%)$. Sedangakan pada parameter produksi panjang buah $(11,29 \%)$, diameter buah $(0,52 \%)$, jumlah buah $(7,32 \%)$, berat buah pertanaman $(2,47 \%)$, berat buah $\mathrm{ha}^{-1}$ $(2,45 \%)$, berat berangkasan segar per tanaman $(6,92 \%)$, berat brangkasan segar ha $^{-1}(6,95 \%)$ dan indeks panen $(0,22 \%)$.

2. Dosis 3 liter ha ${ }^{-1}$ Pupuk Organik Cair dapat memberikan peningkatan pertumbuhan dan hasil tanaman terung yang optimal yakni pada variabel pertumbuhan; tinggi tanaman $\left(24,00,46,40\right.$ sampai $\left.94,80 \mathrm{~cm} \mathrm{tan}^{-1}\right)$, jumlah daun $(15,25,18,50$ sampai 20,50 helai $\tan ^{-1}$ ) dan luas daun $\left(46,07,115,63\right.$ sampai $243,58 \mathrm{~cm}^{2} \tan ^{-}$ $\left.{ }^{1}\right)$. Sedangkan pada parameter produksi; jumlah buah (5,76 buah $\tan ^{-}$ $\left.{ }^{1}\right)$, panjang buah $\left(17,84 \mathrm{~cm} \mathrm{tan}^{-1}\right)$, diameter buah $\left(51,53 \mathrm{~cm} \mathrm{tan}^{-1}\right)$, berat buah $\tan ^{-1}\left(409,05 \mathrm{gr} \mathrm{tan}^{-1}\right)$ dan berat buah perhektar $\left(29,00\right.$ ton $\left.\tan ^{-1}\right)$,berat berangkasan segar $\left(472,36\right.$ gr $\tan ^{-}$ ${ }^{1}$ ), berat berangkasan segar per hektar
(34,72 ton $\left.\tan ^{-1}\right)$, dan Indeks panen $(1,05)$.

\section{Ucapan Terima Kasih}

Pada kesempatan ini penulis ingin mengucapkan terima kasih kepada semua pihak yang telah membantu dengan caranya masing-masing dalam melengkapi tulisan ini.

\section{DAFTAR PUSTAKA}

Badan Penelitian dan Pengembangan Pertanian. 2011. Hortikultura. Departamen Pertanian. Jakarta.

Badan Pusat Statistik Provinsi NTT. 2011. Publikasi NTT Dalam Angka. Kupang.

Dinas Pertanian Kabupaten Ende. 2011. Potensi Lahan dan Produksi Tanaman Hortikultura. Ende.

Gomez, K.A., Gomez, A.A. 1995. Prosedur Statistik Untuk Penelitian Pertanian. Jakarta. Universitas Indonesia Press.

Ignasius H.,Irianto.,Riduan A. 2014. Respon Tanaman Terung (Solanum melongena L.) Terhadap Pemberian Pupuk Organik Cair Urine Sapi. Jurnal Jambi Seri Sains. Vol. 16 (1): 31-38.

Parman S. 2007. Pengaruh Pemberian Pupuk Organik Cair Terhadap Pertumbuhan dan Produksi Kentang (Solanum tuberosum L.). Buletin Anatomi dan Fisiologi. Vol. 15 (2): 21-31.

Susila A.D. 2006. Panduan Budidaya Tanaman Sayuran. Departemen Agronomi dan Hortikultura-Institut Pertanian Bogor. 